\title{
RESULTS OF PASTURE ESTABLISHMENT TRIALS
}

By P. D. SEARS, Grasslands Division, Department of Scientific and Industrial Research, Palmerston

North. (Read by R. W. BROUGHAM).

There is no simple recipe for successful pasture establishment. Many factors have to be considered and each programme adjusted to ensure a good even strike of the sown species, to maintain a vigorous and balanced growth of all without undue suppression of any, and to control weeds.

This paper is a report of 4 trials carried out at Grasslands, Palmerston North, and presents further results of our programme of analysing the complex of factors involved in high-production pastures. Some of the results of this programme have already been presented.

At the 1950 Conference of this Association the writer reported (1) results of cutting or grazing new pastures at different heights during the first few months after sowing. It was clearly shown with broadcast sowings of 201b. of short-rotation, H1, 201b. of perennial, 3lb. of white, and 4lb. of red clover per acre -on-land--of-medium-fertilitp, that allowing the pasture to get to heights greater than 3in. in the early stages gave a considerable clover suppression, although total production during this first period was increased with increase in pasture height. At the 1952 Conference Brougham (2) reported results of similar trials, but with 'difference in seeding rates of short-rotation ryegrass. Lighter seeding rates $(151 \mathrm{lb}$. per acre). gave better total pasture establishment than heavier rates (401b. per acre), with less clover suppression and with better tillering of the individual ryegrass plants. With lighter rates there was greater flexibility in early grazing height-due-to-the-stronger clover growth.

Other recent field trial results from this Division include those of Suckling (3) in which close grazing control was shown to be essential in oversowing on established hill pastures, and of Hyde and Sears (4), 
who described a roller-drill designed to give seed and fertiliser placement at moisture levels and also for even spreading and coverage of this seed.

\section{Trial 1: Effect of Early Grazing Height}

This was a duplicate of the final grazing trial reported in my paper to the 1950 Conference. A flat area of 1 acre of medium fertility was ploughed in January 1950 and cultivated until March 1950. The whole area was then broadcast with $3 \mathrm{cwt}$. of superphosphate per acre and the following seed mixture:-

lb. per acre

Pedigree ,N.Z. short-rotation ryegrass . 20

$"$ " perennial ryegrass . . 20

$"$ " white clover . . 3

" " " broad red clover . . 3

The area was fenced into separate paddocks to give three replicates of the following treatments:1. Grazed at the 3in. stage until 27-10-50 then at 6in. until end September 1951.

2. Grazed at the 9in stage until 27-10-50 then at 6in. until end September 1951.

These two growth heights were determined on the general level of growth over the whole paddock rather than from the length of individual leaves. Production measurements were made using two $10 \mathrm{ft}$. $\mathrm{x}$ 4ft. wire-covered cages placed within each paddock before each grazing and the herbage cut with hand shears down to the general grazed height after grazing, which in all cases was close to a general level of lin. Clover plant counts were made on 12 random sq. ft. areas in each paddock at intervals through the trial.

Yield data are shown in Table 1. It is seen that the results closely parallel those in the previous trial, viz.., the 9in. early grazing height resulted in much less clover than the 3in. early grazing height. Although total production was greater in the first few months from the gin. grazing, this position was reversed after the end of the first period. Quality (as indicated by $\mathrm{N} \%$ ) of herbage was better throughout in the 3in. treatment.

The clover plant numbers were also very similar to those, in the previous trial. At establishment (20-4-50) both. series showed a mean of 16 white and 12 red clover seedlings per sq. ft. ; at 10-S-50 the $3 \mathrm{in}$. grazing treatment had 16 white and 6 red, and the 142 
9in. grazing treatment had 7 white and 4 red ; at 13-11-50, just after the end of the treatments, the $3 \mathrm{in}$. treatment still had 14 white and 6 red and the $9 \mathrm{in}$. grazing had only 5 white and 4 red clover plants per sq. ft. All these grazing treatment differences were highly significant. In addition there were considerable differences in clover plant size and vigour, the plants under the 9in. pasture being etiolated and with few leaves, while those under the 3in. treatment had vigorous crowns and robust root systems.

\section{Trial 2: Effect of Soil Nitrogen Levels at Sowing}

This was a replicated split-plot trial sown in March 1952 on an area which had been through a continuous cropping and cultivation cycle and was thus very low in soil nitrogen. Four randomised blocks of the following broadcast mixtures were laid down:-

lb. per acre

a $b$

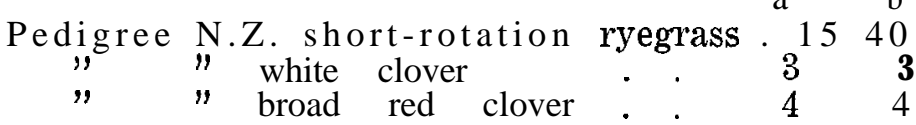

1. Low soil nitrogen at sowing-No return of urine.

Each main plot was then split into 4 and the following treatments were randomised within each main plot :-

2. High soil nitrogen at sowing-No return of urine.

3. Low soil nitrogen at sowing-Return of urine.

4. High soil nitrogen at sowing-Return of urine.

The soil nitrogen levels were' increased on treatments 2 and 4_by_mixing_urea-into the-soil-at-3cwt. per acre ; the whole area also received lime, superphosphate, potash, and magnesium sulphate 'at heavy rates to ensure adequate minerals to all treatments.

The strike of all species was good and measurements commenced after a trimming cut on 20-4-52. All herbage was mown to a level of $\frac{1}{2} \mathrm{in}$. from each plot every time the herbage on the fastest growing plot reached 3in. The urine returned was collected from cows grazing good pasture; to each plot the amount returned contained 80 per cent of the total $\mathrm{N}$ in the herbage from that plot, the calculations of these quantities - being based on chemical analyses of the herbage and urine at each cut. The urine was poured over the plots in "doses" of approximately $150 \mathrm{cc}$ to simulate actual urine return by grazing sheep. Dung was not returned because it is much slower in effect (5) and also because the soil was high in minerals. 


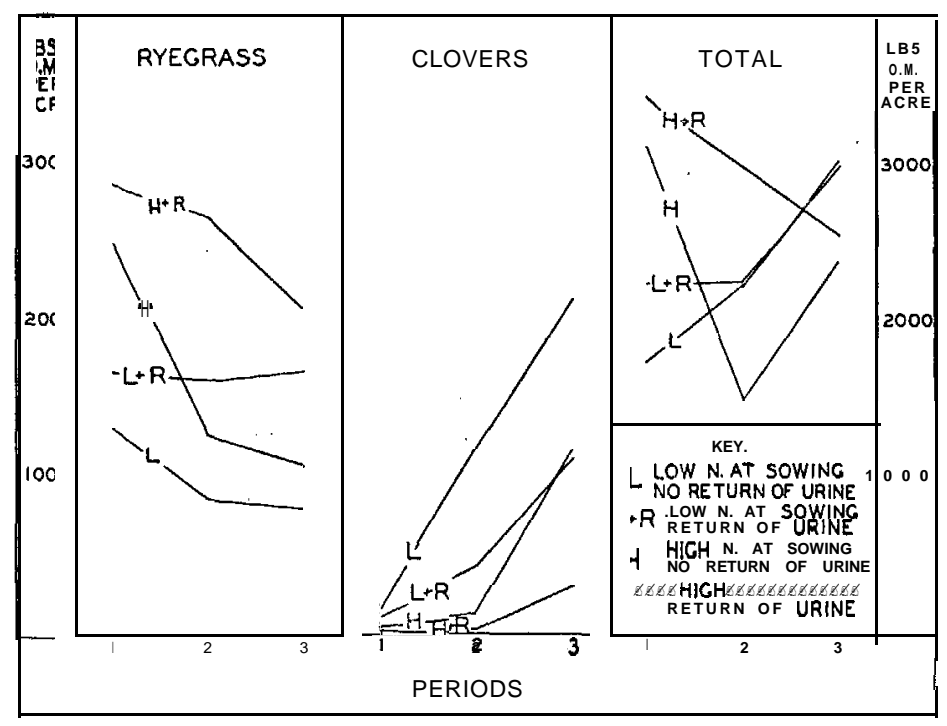

Fig. I

Botanical analyses were made by dissection of samples from each plot at each cut, the clover counts were made on $2 \mathrm{sq}$. $\mathrm{ft}$. areas selected at random on each plot. Although there were no pure clover sowings included to check on any direct damage from the urea, observations gave no cause to believe there was in fact any such damage. In this trial the clovers grew well along the plot boundaries of the high $\mathrm{N}$ plots, and also in the next trial' there was good clover growth on the surrounding pathways, which were also treated with urea, but which were under continuous mowing without return of urine.

\section{Results}

Fig. 1 presents the pasture yields and composition under the 4 main treatments for 3 periods during the trial. The data from the seeding rates are not shown separately, as in this trial the only measure differences were slightly less ryegrass growth and more Poa annua and clover on the lighter grass rates for the first few cuts. The cutting at the 3 in. stage throughout would, of course, be an important factor in reducing differences from the grass seed rates. It is also the best practicable defoliation. height to the advantage of the young clovers.

The main treatment effects were:- 
1. Low soil $\mathbf{N}$ at sowing without return of urine produced pasture with lowest grass yield in the early stages (crude protein 22 per cent of D.M.). Then followed a period of rapid increase in total yield from the vigorous early clover development. In the final period the yield was very high, but there was very marked clover dominance, although the grass was increasing after a long period of obvious nitrogen deficiency. The herbage from this treatment produced bloat every time it was fed to stall-fed cows, in contrast to the herbage from treatment 4.

2. High soil $\mathbf{N}$ at sowing without return of urine gave a very high initial dark-green grass growth (crude protein 30 per cent of D.M.), but only a very small early clover growth. After about the middle of August there was a marked slump in the ryegrass with a change to yellowish leaf coloration. No doubt this was due to nitrogen shortage, for much $\mathrm{N}$ had been removed in the heavy initial grass yield and none was returned in urine and little supplied by clovers. The few clovers surviving the early grass competition and also some new volunteer clover seedlings made good growth in the final period, and the pasture development after this resembled closely the pattern followed earlier under the previous treatment.

3. Low soil $\mathbf{N}$ at sowing with return of urine produced pasture significantly higher in total ryegrass and lower in clover production than the first treatment, but lower in grass and higher in clovers than the other two treatments in the early period ; from then on total production was the same as in the first treatment.

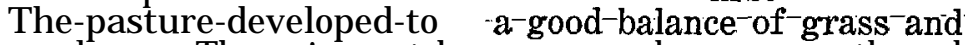
clover. The urine patches gave good grass growth and the clovers were able to keep pace in between the patches. At the end of the trial this treatment was the highest producing of all with a dark-green colour and a crude protein content of 22 per cent of D.M.

4. High soil $\mathbf{N}$ at sowing with return of urine gave the greatest grass growth and the lowest clover growth throughout. The clover seedlings were doubtless suppressed by grass competition and by toxic effects of the urine (6). The amounts of urine returned were much greater-in-the-early-period-on-this treatment than on the low $\mathrm{N}+$ return treatment. Vigorous grass growth was, however, mzintained only to about the middle of October, after which there was a marked slump. This was doubtless due to the cum- 
ulative effects of leaching of nitrate and losses of ammonia from the urine. The return of urine delayed the onset of nitrogen deficiency, but did not obviate it in those plots where clovers were sparse. At the en'd of the trial the pasture was very open. The grass was yellow-green (crude protein 14 per cent. of D.M.). There was only a very small amount of clover growth supplied by the few survivors from the original sowing and some volunteers.

It must be appreciated that the buried clover seed content in all this soil is very high ; in areas where there is only little buried seed of good clover strain this treatment would undoubtedly give a final pasture very little different from a sowing without any clover seed.

Clover plant counts made on 28-7-52 gave mean numbers per sq. $\mathrm{ft}$. of 8 white and 4 red clover on the high $\mathrm{N}$, and 19 white and 8 red clover on the low $\mathrm{N}$, these differences being highly significant. These differences resemble closely the differences in the previous grazing trial between the 3in. and 9in. grazing heights on medium nitrogen soil. Similar differences in plant size and vigour were also observed. Differences in plant numbers between other treatments were much smaller and did not reach significance, although the clovers in the non-return series were more numerous and appeared to be more vigorous.

\section{Trial 3 : Effect of early grazing height on pasture sown on high $\mathbf{N}$ soil.}

This was a replicated factorial trial sown at the same time on an area adjacent to Trial 2. Each of the 4 blocks contained the following 8 treatments in random order :-

1. Cut at 3in. from date of sowing up to 25-10-52.

2. Cut at 9in. from date of sowing up to 25-10-52.

3. Cut at 3in. until 28-7-52, then at 9in. up to 25-10-52.

4. Cut at 9in. until 28-7-52, then at 3in. up to 25-10-52, each of these 4 being associated with both of the seed mixtures of Trial 2 . There were thus 8 replications of the cutting treatments. The soil nutrient level of the whole area, including pathways, was similarly increased with artificial N, P, K, Mg and S, and thus treatment 1 is comparable to treatment 4 of Trial 2.

Data are not presented in detail, but the following results were obtained :- 
1. Clover growth was good on all pathways which were under continuous mowing without any return of nutrients.

2. No sustained differences from seeding rate were obtained, grass growth being strong and clovers weak in all plots.

3. Yields and composition of herbage in the 3in. cutting treatments paralleled closely those in treatment 4 of Trial 2. The yields from the 9in. treatments were much greater during the first few months. Up to 28-10-52 the total yield in the 3in. treatments was 58001b. of D.M. per acre and in the 9in. treatments was $8800 \mathrm{lb}$. of D.M. per acre, with the yields of the reversed treatments falling between these.

4. Clover suppression was almost complete in the treatments cut at 9in. throughout, and greater in those cut at 9in. up to 28-7-52, than in the 3in. treatments, although even in these the clover suppression was severe.

5. After the trial period had ended half of each plot was cut as silage, and the other half was similarly cut with urine return. There was considerably more subsequent growth of. the surviving and volunteer clovers in the "cropped" than in the "grazed" areas.

\section{Trial 4: Effect of cropping prior to sowing pasture} mixture.

This trial, which was unreplicated, compared on paddock- scale--grass-to-grass-sowing-with-sowing-afterforage cropping with rape. In spring 1950 half of a uniform area of highly productive pasture was ploughed and sown to rape, the other half remaining under rotational grazing. In autumn 1951 this rape crop ( 80001 b. of D.M. per acre-2.3 per cent N) was cut and discarded, and the area sown with Italian ryegrass, which was later also cut and removed (3300 lb. of D.M.-1.8 per cent N). Thus by spring 1951 this cropped area had been depleted of fertility while that of the pasture area remained at a high level. Both the cropped and the pasture area were-thenheavily topdressed with minerals and ploughed, after which one half of each was sown with rape and the other with a pasture mixture of-201b. of short-rotation ryegrass, $3 \mathrm{lb}$. of white, and $41 \mathrm{~b}$. of red clover per acre. 
The yield (by February 1951) of the rape crop sown on the land low in nitrogen after the previous cropping was only $2000 \mathrm{lb}$. of D.M., whereas that sown directly after the good pasture was again $80001 \mathrm{~b}$. of D.M. For the same period the two pastures each produced a total yield of $74001 \mathrm{~b}$. of D.M., but the pasture sown on the nitrogen-deficient soil was dominated by the red clover before developing a good balance, whereas that sown on the nitrogen-rich soil maintained grass dominance throughout. The season was wet and this grass-dominant pasture probably produced more than normal for such a spring sowing.

There was thus a considerable advantage in sowing the low-nitrogen soil direct to pasture rather than to get a poor rape crop; whereas at the other extreme the balance was in favour of first cropping out the high-nitrogen soil, both from the viewpoint of feed supply in summer and of pasture establishment.

\section{GENERAL DISCUSSION}

The results of these trials have in my view added a few more points for consideration in any pasture establishment programme, and when added to the previous results quoted at least demonstrate that cropping rotations, pasture seed mixtures, and early grazing management are not easily fitted into a single recipe applicable to all farms.

Many other factors will, of course, influence final decisions on what course to follow on any farm at any time. For example, liability to winter poaching on heavy land, fencing and watering facilities on new land, special feed requirements for such troubles as bloat (7) and facial eczema, and considerations of seed cropping can all be major factors influencing pasture mixtures. Also, there are a multitude of possibilities on the cropping side to adjust fertility levels and for best economic return. The use of artificial nitrogen, though expensive, can also be valuable under some circumstances.

In the early management of new pastures grazing by the "on and off" system or as a "day" paddock only can be used to reduce excess nitrogen and, grass competition (8). With very careful management, the cereal and grass components of a new pasture can even be used as a tall "crop", with cutting or feeding off on the above principle and with the later oversowing of the clovers to get a final good balance., For some 
TABLE 1: EFFECTS OF EARLY GRAZING AT DIFFERENT HEIGHTS ON PASTURE YIELDS AND COMPOSITION-TRIAL 1.

\begin{tabular}{|c|c|c|c|c|c|c|c|}
\hline \multirow[b]{2}{*}{ Main Treatment } & \multirow[b]{2}{*}{$\begin{array}{l}\text { No. of } \\
\text { Grazings }\end{array}$} & \multirow[b]{2}{*}{$\begin{array}{l}\text { Period } \\
\text { Ending }\end{array}$} & \multirow[b]{2}{*}{$\begin{array}{l}\text { Total Yield } \\
\text { (lb. D.M. } \\
\text { per acre) }\end{array}$} & \multicolumn{3}{|c|}{$\begin{array}{l}\text { Botanical Constituents } \\
\text { (lb. per acre) }\end{array}$} & \multirow[b]{2}{*}{$\begin{array}{l}\text { Crude } \\
\text { Protein } \\
\text { (\% of } \\
\text { D.M.) }\end{array}$} \\
\hline & & & & Ryegrass & White & $\begin{array}{c}\text { Red } \\
\text { Clover }\end{array}$ & \\
\hline $\begin{array}{l}\text { Grazed at 3in. up to } \\
27.10 .50 \text { then at } 6 \mathrm{in} . \\
\text { until end Sept., } 1951\end{array}$ & $\begin{array}{l}8 \\
5 \\
5\end{array}$ & $\begin{array}{l}25.10 .50 \\
31.3 .51 \\
31.9 .51\end{array}$ & $\begin{array}{l}5130 \\
9020 \\
4100\end{array}$ & $\begin{array}{l}5000 \\
2820 \\
2100\end{array}$ & $\begin{array}{r}60 \\
1270 \\
1200\end{array}$ & $\begin{array}{r}70 \\
4930 \\
800\end{array}$ & $\begin{array}{l}27.1 \\
20.6 \\
24.1\end{array}$ \\
\hline $\begin{array}{l}\text { Grazed at 9in, to } \\
27.10 .50 \text { then at up' } 6 \text { in. } \\
\text { until end Sept., } 1951\end{array}$ & $\begin{array}{l}3 \\
\mathbf{5} \\
\mathbf{5}\end{array}$ & $\begin{array}{r}25.10 .50 \\
31.3 .51 \\
31.9 .51\end{array}$ & $\begin{array}{l}6650 \\
6680 \\
2800\end{array}$ & $\begin{array}{l}6650 \\
4890 \\
2400\end{array}$ & $\begin{array}{l}\text { Tr. } \\
320 \\
260\end{array}$ & $\begin{array}{r}\mathrm{Tr} \\
1470 \\
140\end{array}$ & $\begin{array}{l}21.5 \\
15.9 \\
18.6\end{array}$ \\
\hline
\end{tabular}

All treatment differences shown are significant at the 5 per cent. level and the ryegrass and red clover yield differences in the second period are significant at the 1 per cent. level. 
conditions this can be very useful, as it saves a ploughing and also gives a large feed supply for the early spring.

All these points must be considered along with seed quality, species growth, and the mechanics of actual sowing. One feels, however, that the main requirement in all such planning is a full appreciation of the basic factors involved in early pasture growth.

\section{REFERENCES}

(1) Sears, P.D. (1950) Proc. XIIth Conf. N.Z. Grasslands Assn., p. 132.

(2) Brougham,' R.W. (1952) Proc. XIVth Conf. N.Z. Grasslands Assn., p. 172.

(3) Suckling, F. E. T. (1949) Proc. XIth Conf. N.Z. Grasslands Assn., p. 89.

(4) Sears, P.D. (1951) Proc. Massey Agric. College Dairyfarming Week, pp. 7-21.

(5) Sears, P.D. and Newbold, R. P. (1942) N.Z. J. Sc. $\&$ Tech. 24, 36A-61A.

(6) Doak, B. W. (1953) Journal Agric. Sc. (in press).

(7) Sears, P.D. (1953) Proc. Massey Agric. College Dairyfarming Week

(8) Sears, P.D. (1953) N.Z. J. Sc. \& Tech.

\section{DISCUSSION}

In answer to a suggestion that the results of the trials reported might create a false impression among farmers, who worked on the assumption that low nitrogen on a farm means no nitrogen Dr Melville stated: "In this paper Sears is drawing on some 15 years' experience of the nitrogen cycle in established and establishing pastures. It would have been perhaps more accurate to talk of low available soil nitrogen, but there can be little doubt of the soundness of his conclusions.

Our criterion that available soil nitrogen is low is that applied nitrogen should give a marked response in growth and that simulttaneously the nitrogen content of the leaves should greatly increase. It is relatively easy to exhaust our fertile Manawatu soils of available nitrogen to virtually the same stage as that reached on pumice country." 